\title{
A folyóiratcikkek súlya a különféle tudományterületek szakirodalmában: az elmúlt két évtized trendjei
}

\author{
Schubert András - Soós Sándor \\ MTA Könyvtár és Információs Központ, Tudománypolitikai és Tudományelemzési Osztály, Budapest
}

\begin{abstract}
Vizsgálatunk során a folyóiratcikkek arányát hasonlítottuk össze néhány természettudományi, valamint társadalom- és bölcsészettudományi szakterület összefoglaló (review) cikkeinek irodalomjegyzékében. Megállapítottuk, hogy az 1995-2014 időszakban a folyóiratcikkek aránya mindegyik vizsgált területen növekedett. A legintenzívebb növekedés a társadalomtudományi területen volt tapasztalható. Orv. Hetil., 2015, 156(24), 985-987.
\end{abstract}

Kulcsszavak: tudománymetria, folyóiratcikkek súlya, természettudományok, társadalom- és bölcsészettudományok

\section{Disciplinary trends of preferred publication channels as reflected in the references of review papers}

\begin{abstract}
Trends of preferred publication channels in selected categories of Sciences, Social Sciences and Arts \& Humanities were studied by determining the percentage share of references in reviews to serials (journals) in all references. It was found that in the period 1995-2014, the fraction of articles published in journals was increasing in all selected areas of science and scholarship. The most dynamical increase was found in Social Sciences.
\end{abstract}

Keywords: scientometrics, weight of journal articles, sciences, social sciences and humanities

Schubert, A., Soós, S. [Disciplinary trends of preferred publication channels as reflected in the references of review papers]. Orv. Hetil., 2015, 156(24), 985-987.

(Beérkezett: 2015. február 12.; elfogadva: 2015. február 26.)

Közismert, hogy míg a természettudományokban a folyóiratcikkek jelentik a kutatási eredmények publikálásának legfontosabb formáját, a társadalom- és bölcsészettudományokban más publikálási formák (könyv, múvészeti katalógus, újságcikk stb.) is nagy jelentőségűek lehetnek. Nehéz azonban megbízható és összehasonlítható információt szerezni a különböző publikációtípusok számszerü arányairól az egyes szakterületeken, mert a nagy multidiszciplináris adatbázisok (Web of Knowledge, Scopus), amelyek alapján az ilyenfajta vizsgálatokat végezni szokták, döntő többségben a folyóirat-irodalmat tartalmazzák minden területen. A fellelhető szakirodalom főként nemzeti adatbázisok alapján készült nemzeti szintü eredményeket tartalmaz (lásd például: $[1,2,3]$ ).

Glänzel és Schoepflin ötlete nyomán [4] azonban közvetett információkat szerezhetünk ezekből az adat- bázisokból a folyóiratokon kívüli világról is, ha a folyóiratcikkek irodalomjegyzékét (a hivatkozásokat) tanulmányozzuk.

Ezt az utat követtük a jelen vizsgálat során is. Az eredeti ötletet azzal egészítettük ki, hogy vizsgálatunkat az összefoglaló jellegű („review”) cikkekre korlátoztuk. Mivel a review cikkek célja az, hogy összegyüjtsön minden, az adott témában releváns irodalmat a származás, megjelenés helyétôl függetlenül, joggal remélhettük, hogy ezek a hivatkozások átfogó képet mutatnak egy adott téma teljes irodalmáról.

Az ebben a tanulmányban bemutatott adatok egy nagyobb átfogó kutatás első, előzetes publikált eredményei, amelyből azonban reményeink szerint már kiolvashatók bizonyos általános mintázatok és tendenciák. 


\section{Adatforrások és adatfeldolgozás}

Vizsgálatunkat a Web of Knowledge (WoK) adatbázisnak az 1995-2014 időszakra vonatkozó adatai alapján végeztük. Mintáinkat az élő és élettelen természettudományok, valamint a társadalom- és a bölcsészettudományok egy-egy területéről gyűjtöttük. A szakterületek kiválasztásában tartalmi és technikai szempontok is szerepet játszottak. Igyekeztünk minden nagy területnek egy reprezentatív, a terület térképén centrális helyzetú szakterületét kiválasztani. Gondot fordítottunk továbbá arra is, hogy a kiválasztott terület mérete megfelelő legyen: ne legyen túlságosan nagy az adatfeldolgozási munkák ésszerü erőfeszítéssel történő elvégzéséhez, de a vizsgált időszakban legyen elegendő review cikk statisztikailag értékelhető elemzés elvégzéséhez. A kiválasztott szakterületek a sürgősségi orvostan, a spektroszkópia, a szociálpszichológia és a tudománytörténet és -filozófia lettek.

Minden szakterületről letöltöttük a WoK által „Review” publikációtípusba sorolt cikkek adatait, és ezeknek a hivatkozásjegyzékeit elemeztük.

A hivatkozásokat adatelemekre bontottuk, és a review publikálását közvetlenül megelőző 5 évre vonatkozó hivatkozásokat különválasztottuk. A statisztikai vizsgálatainkhoz az erre az ötéves időszakra vonatkozó hivatkozásokat használtuk fel. Ezen a módon kívántuk biztosítani azt, hogy a trendvizsgálatok során az egyes forrásévekhez tartozó hivatkozásállományok közvetlenül összevethetők legyenek.

Egy hivatkozást akkor tekintettünk folyóiratcikkre vonatkozónak, ha a következő kritériumok bármelyike teljesült:

- a DOI adatmező nem volt üres;

- a kötet- és oldalszámmezők nem voltak üresek;

- a forrásmező folyóiratcímre utaló megnevezést tartalmazott, és a kötet- vagy az oldalszámmező nem volt üres.
1. táblázat A négy kiválasztott szakterület összesített mutatószámai az 1995-2014 időszakra

\begin{tabular}{lrcrcc}
\hline & Cikk & Rev & Ref/rev & $\begin{array}{l}\text { Price- } \\
\text { index }\end{array}$ & Folyóirat \\
\hline Sürgósségi orvostan & 60197 & $3,7 \%$ & 58,8 & $32,1 \%$ & $90,5 \%$ \\
Spektroszkópia & 141473 & $2,1 \%$ & 184,2 & $30,8 \%$ & $92,3 \%$ \\
Szociálpszichológia & 86496 & $1,9 \%$ & 152,5 & $26,8 \%$ & $72,0 \%$ \\
Tudománytörténet és & 63090 & $3,3 \%$ & 106,0 & $10,3 \%$ & $45,1 \%$ \\
-filozófia & & & & & \\
\hline
\end{tabular}

Cikk: A szakterület összes cikkeinek száma.

Rev: A review cikkek százalékos részesedése az összes cikkből. Ref/rev: Az egy review cikkben található átlagos hivatkozásszám. Folyóirat: A folyóiratcikkek aránya hivatkozások között.

\section{Eredmények}

Az 1. táblázatban foglaljuk össze a négy kiválasztott szakterületnek az 1995-2014 időszakra vonatkozó öszszesített mutatószámait.

A Price-index de Solla Price munkája nyomán [5] a „kemény” és „puha” tudományok közötti különbséget hivatott kvantifikálni. Magának a „keménységnek” nincsen egyértelmű definíciója. Egyesek szerint a módszertani szigor, az egzaktság és az objektivitás a fó kritériumok. Elfogadhatónak látszik az a vélekedés is, miszerint a kemény tudományokban a mérhető, kvantifikálható tényeknek, a puhákban a verbális érvelésnek, a hagyományoknak és a spekulációnak van nagyobb szerepük.

Definíciója szerint a Price-index a hivatkozásoknak a megjelenést közvetlenül megelőző öt évre vonatkozó hányadával egyenlő. A „kemény” természettudományokban ez a hányad általában lényegesen magasabb, mint a „puhább” társadalom- és bölcsészettudományokban. Természetesen az index értékét sok más tényező is befolyásolja, például a gyorsan fejlődo, „divatos” területeken az index értéke a „keménységtől” függetlenül igen magas lehet. A folyóiratcikkek arányának időbeli változását az 1 ábra mutatja be.

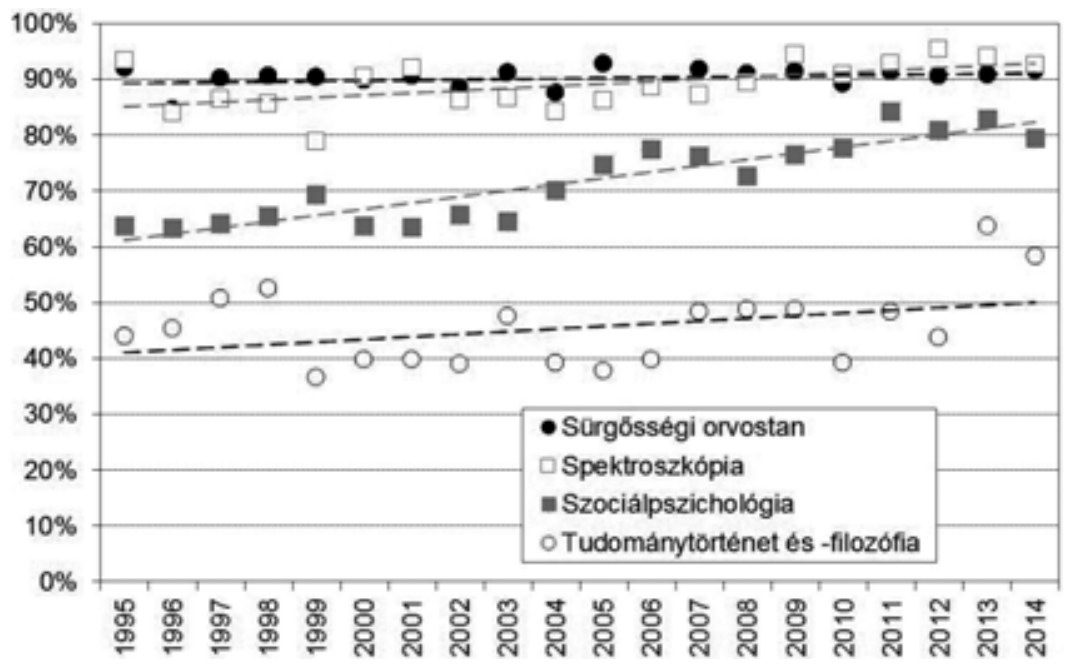

l. ábra | A folyóiratcikkek aránya a négy kiválasztott szakterület review cikkeinek hivatkozásai között az 1995-2014 időszakban 


\section{Az eredmények értékelése}

\section{Összesitett mutatószámok}

A cikkek számából és a review cikkek arányából nem szabad semmilyen következtetést levonnunk, mert a szakterületek kiválasztása részben pontosan ezeknek a mutatószámoknak az alapján történt. Az egy review cikkre eső hivatkozások száma természetesen mindenütt magas; ez lényegében azt igazolja vissza, hogy a WoK adatbázis "Review” publikációtípusának kiválasztási elvei megfelelőek. A szakterületek között tapasztalható különbségek a több szakterületre kiterjedő részletesebb vizsgálatok elkészültéig esetlegesnek tekinthetőek.

A Price-index a várakozásoknak megfelelően mutatja: a természettudományok 30\% fölötti értékétől a társadalomtudományokat reprezentáló szakterület elmarad, a bölcsészettudományi szakterület Price-indexe pedig alig haladja meg a $10 \%$-ot.

Nagyon hasonló mintázatot követ a folyóiratcikkek aránya a review cikkek hivatkozásai között. A természettudományokban ez az érték 90\% fölötti, a bölcsészettudományokban az 50\%-ot sem éri el. Ez megerősíti Glänzel és Schoepflin [4] másfél évtizedes eredményeit.

\section{A folyóiratcikkek arányának változása az időben}

Az 1. ábrán a szaggatott vonallal rajzolt egyenesek mutatják a lineáris trendeket. Mindegyik egyenes emelkedik. A természettudományokban, ahol már a vizsgált időszak kezdetén 90\% körüli értékeket találunk, természetesen az emelkedés már csak igen csekély mértékű lehet. A leglátványosabb növekedést a társadalomtudományi szakterület mutatja, ahol az időszak végére a folyóiratcikkek aránya megközelíti a természettudományokét. A több szakterületre kiterjedő, folyamatban lévő vizsgálat előzetes eredményei szerint ez - ha esetleg kevésbé látványos módon - általános jelenség a társadalomtudományokban. Úgyszintén általánosnak mondható a kiválasztott bölcsészettudományi szakterület viselkedése: a folyóiratcikkek arányának növekedése mérsékelt, és az értékek igen nagy fluktuációt mutatnak.

\section{Következtetések}

Általános következtetésként elmondhatjuk, hogy az elmúlt húsz évben a vizsgált szakterületeken a folyóiratcikkek jelentősége nőtt.
Még a természettudományokban is, ahol amúgy is a legmagasabb a folyóiratcikkek aránya, egyértelmú növekedést tapasztaltunk, még ha ez - a 100\% felé közeledve - természetesen fékeződik.

A folyóiratcikkek térhódítása a társadalomtudományokban a legerőteljesebb: a vizsgált időszak végére arányuk a természettudományokét közelíti. Telítődés, fékeződés jele nem tapasztalható.

A bölcsészettudományokban a nagy fluktuáció miatt a növekedés szignifikanciája kérdéses.

Úgy gondoljuk, hogy az itt használt mutatószám - a folyóiratcikkek aránya a review cikkek hivatkozásai között - a Price-indexet kiegészítve minden korábbinál árnyaltabb képet ad a szakterületek „keménységi dimenziójáról”.

Anyagi támogatás: A szerzők köszönik az FP7SSH-2013-2 \#613202 (IMPACT-EV) projekt támogatását.

Szerzői munkamegosztás: A két szerző a kézirat megírásában 50-50\%-os arányban vett részt. A szerzők a cikk végleges változatát elolvasták és jóváhagyták.

Érdekeltségek: A szerzőknek nincsenek érdekeltségeik.

\section{Irodalom}

[1] Creaser, C., Oppenheim, C., Summers, M. A.: What do UK academics cite? An analysis of references cited in UK scholarly outputs. Scientometrics, 2011, 86(3), 613-627.

[2] Hammarfelt, B.: Using altmetrics for assessing research impact in the humanities. Scientometrics, 2014, 101(2), 1419-1430.

[3] Puuska, H. M., Miettinen, M.: Disciplinary differences in publishing practices. [Julkaisukäytännöt eri tieteenaloilla.] 2008, Opetusministeriön julkaisuja (Publications of Finnish Ministry of Education). [Finnish]

[4] Glänzel, W., Schoepflin, U.: A bibliometric study of reference literature in the sciences and social sciences. Information Processing and Management, 1999, 35(1), 31-44.

[5] De Solla Price, D. J.: Citation measures of hard science, soft science, technology, and nonscience. In: Nelson, C. E., Pollock, D. K. (eds.): Communication Among Scientists and Engineers. Columbia University Press, New York, USA, 1986, 155-179.
(Schubert András e-mail: schuba@iif.hu) 